\title{
Proposal of a Reference Model for Fashionable and Healthy Goods production in SME networks
}

\author{
Valentina Franchini ${ }^{1}$, João Bastos ${ }^{2}$, Américo Azevedo ${ }^{2}$, Rosanna Fornasiero ${ }^{3}$ \\ ${ }^{1}$ SYNESIS consortium - Viale Fulvio Testi, 128, Cinisello Balsamo, Milano, Italy, \\ valentina.franchini@synesis-consortium.eu \\ ${ }^{2}$ INESC Porto, Campus da FEUP, Rua Dr Roberto Frias 378, 4200-465 Porto, Portugal, \\ \{joao.bastos,ala\}@fe.up.pt \\ ${ }^{3}$ ITIA-CNR, Via Bassini 15, 20133 Milano, Italy, rosanna.fornasiero@itia.cnr.it
}

\begin{abstract}
In order to stay competitive, European manufacturing companies need to enter new market segments implementing innovative production methodologies to strengthen their collaborative networks. Consumer needs and expectations of specific target groups - such as elderly, obese, disabled, or diabetic persons - are arising as challenging opportunities for European consumer goods companies which are asked to supply small series of functional and fashionable products of high quality, affordable price and eco-compatible. This paper aims at proposing an innovative collaborative Reference Model that supports in Textile, Clothing and Footwear (TCF) supply networks in meeting the needs of specific consumer target groups.
\end{abstract}

\section{Keywords}

Reference Model, Collaborative Supply network, Fashion companies.

\section{Introduction}

Nowadays, the EU's population is over 500 million people and project target groups cover an important part of it since elderly persons (over 65) are 17\% of the overall population, obese people $26 \%$, diabetics $10 \%$ and disabled people $10 \%$. Furthermore, overweight people are $50 \%$ and people with reduced mobility are more than $40 \%$ of the population (European Commission, 2007). Even when it is considered overlapping among the target groups (e.g. many obese people are also diabetic) these figures still represent an important share of the overall population.

Over the past decades with the increasing globalization, the industrial enterprises were forced to update their supply network strategy in line with the new and challenging circumstances of a globalized and competitive market. Thus, company managers put a growing interest in developing strategies design to provide companies with resources and capabilities in order to compete successfully in the market.

Especially in the last years, the global financial crisis and the emerging of new technologies to be exploited in many different context, the organizational paradigm has changed, leading companies to focus on activities where they are really competitive and networking with strategic partners.

In fact, the combined effects of labour intensity, low entry and exit barriers, and changes in international trade regulations have made TCF a global industry where competition is planetary and key players are no longer concentrated only in Europe and North America but 
located in emerging low labour cost countries (Gereffi, et al. 2005). Small firms have struggled to survive, often unsuccessfully, and have been progressively weeded out (Leonidou 2004). Moreover, the overall performance of this industry is deeply affected by unpredictable and seasonal demand as well as emerging consumers' needs in terms of comfort, health and environmental attention.

Consumers are increasingly demanding for personalization and value added of harmonized products in the TCF sector, not only in terms of aesthetics, but also in terms of health, innovative functionalities and environmental impact (Azevedo et al, 2011).

Given this context, the main objective of this research is to develop an innovative Reference Model (RM) for the TCF SMEs companies to support the manufacturing of small batches of products addressing the need of the project consumer target groups (elderly, obese, disabled and diabetic persons). The paper is organized as follows: after an analysis of the existing literature on this specific reference model domain, a description of the case analysis is done and then the reference model is presented in all its dimensions.

\section{Literature Review and Research Development}

Competition within the TCF sector is nowadays among global networks and the key issues are on how to develop and implement innovative managerial models and methods to support collaborative practices (Dyer and Singh, 1998; Camarinha-Matos, 2010).

A new level of complexity is arising, given the fact that competition as well as collaboration schemes are transitioning from between companies to between supply networks. In consequence, management of both inter-organizational and inter-supply chain processes and information is becoming even more critical for rapid response, eco-sustainability and quality assurance of products and processes especially when production involves small series.

Recent research in the field addressed different forms of business networks. They are distinguished for example by value chain orientation (horizontal, vertical, lateral), life span (long-term vs. short-term), degree of virtualization or hierarchical structure (hierarchical vs. non-hierarchical networks) (Camarinha-Matos and Picard, 2008; Grefen, 2009). And yet, most tangible business networks are formed along the value chain and for enduring purposes. Nevertheless, the current market asks for flexible organizational structures which can quickly adapt to new business requirements and sustainability challenges. This new demands are forcing business networks to have much shorter life-time existence and take advantage of new infrastructure technologies supported in distributed information systems and knowledge.

The paradigm of demand-driven supply networks is emerging in literature as a collaborative approach in response to consumer's needs and expectations (Childerhouse et al. 2002; De Treville et al. 2004; Piller, 2003; Boer and Dulio, 2007; Yeung et al., 2010). This implies different approaches to the market based not only on traditional sales channels (shops, retailers) but more and more on an Internet mediated direct contact with consumers both for product conception and for sales.

At the same time, the market increasingly values collaborative networks that endorse the sustainability challenges. Moreover, as Adler (2001) effectively discussed, the new enlarged/extended structures, characterized by high cognitive content exchanges, can no longer be coordinated by traditional hierarchy/market instruments as they require trust to share knowledge and leverage on external, updated and complementary competencies, i.e. Open Innovation model summarized in Romero and Molina (2011).

Collaboration will not only be regarded under the aspect of organizational networking, but also under terms of business sustainability, knowledge networking and ICT networking to 
achieve strategic business goals.

After a deep analysis of some of the most important supply network reference models in literature - among others Value reference model, SCOR model and Collaborative networking organizations, Virtual organization, the SMART model proposed by Filos and Banhan (2001) has been selected as starting point for the reference model to be proposed for the TCF networks. The SMART model is a kind of umbrella covering most important models for collaborative networking based on the following three main dimensions:

1. Knowledge dimension: to map partners' competencies to be shared within the network in terms of products and processes;

2. Information \& Communication Technologies (ICTs) dimension: to support the requirements for the implementation of ICT services at different process levels along the network;

3. Organizational dimension: to provide specifications of the organizational changes for SMEs for structuring supply networks in small series production.

For the scope of this study a new dimension, coherent with eco-efficiency objectives of networking, is added i.e. the Sustainability dimension. This new dimension is intended to support companies in developing of a eco-compatible approach for their products and processes working on the 3 dimensions (knowledge, ICT and organization) for the scope of creating sustainable networks.

\section{Case studies analysis}

Companies belonging to the TCF sector have been selected both among large and SMEs to analyse practices to be transferred from Large enterprises to SMEs as an objective of the research. Secondary level analysis has been done using internet as a mean to explore the strategies and vision especially of large companies. The sample is selected adopting theoretical sampling (Glaser and Strauss, 1967), and multiple investigators are used to reduce bias and create more reliable data (Eisenhardt, 1989; Yin, 1994; Eisenhardt et al., 2007; Pagell, 2004).

An "as is" business process analysis was conducted through focused interviews and BPMN (Business Process Modeling Notation) representation to collect and formalize a rich set of data, both qualitative and quantitative. Furthermore, the requirements of each company were pointed out and analysed in detail to draw the relevant characteristics, procedures and techniques along their supply network.

Within-case analysis allowed to analyse each company singularly and understand their requirements in terms of the four dimensions while a cross-case analysis among the different companies allowed to compare companies behaviours and understand collaboration mechanisms.

\subsection{Cross-Case Analysis among TCF companies}

In TCF supply networks, innovation is strongly market driven, and especially in the latest years companies started to produce smaller lots with a high level of configuration possibilities (both based on aesthetic and functional features) to face competitively the market. Evolving customer needs influence production with requests of personalization and customization of components and/or the materials. From our research it turns out that the capability to answer to product configuration is mainly of large companies with highly industrialized process (see www.store.nike.com/iD) offering many different product variants for their products. Customization and product personalization (meaning design and 
engineering a product for a customer) is mainly of very small companies with limited numbers of models and restricted supply networks. Most of the SMEs in TCF sector are based on a production model where customization and product configuration is still difficult to apply. But the model of mass production is not anymore valid and they need support to shift to configurable production. The cross-case analysis was based on the four dimensions defined in the previous chapter.

Organizational: supply networks in TCF sector is based on long-term relationships with suppliers and outsourcing companies. In case of footwear for example, material and component suppliers are collaboratively involved both during design and product industrialization, since every season each manufacturer has hundreds of models (and related components) to produce. Each of the suppliers has to develop its own component according to information received from the shoe producer (focal company). Companies develop a strong relationship with their outsourcers as well to guarantee the highest quality to their customers, and benefit from their availability and flexibility along the season, according to framework agreement to be signed with them. Some of the time framework agreements are defined at the beginning of each season to have list of partners which can collaborate when orders arrive.

ICTs: manufacturing processes of TCF supply networks are more and more supported by CAD based design starting from the $2 \mathrm{D}$ drafts to $3 \mathrm{D}$ development of models and size. Some companies already have web based application to manage orders from retailers and from customers. One of the analysed SMEs have a product tracking system which allows to the customer to have information about the origin of the product components inserting the number of the barcode in the web B2C platform. Companies are trying to integrate both their processes with up and downstream partners based on advanced ICT systems for the management of the strategic partnerships.

Knowledge: Design capabilities and know-how on production process represent an important competitive advantage for the networks. Each supplier has its own competences about how to deal with its own component and in case of SMEs networks like the one we have analysed with interviews each supplier is in charge of the product component from its design to production. Another level of knowledge when applying a production model based on customization is related to market needs and customer requirements especially when dealing with special groups.

Sustainability: from the cross-case analysis it turns out that large enterprises implement sustainable practices moving to eco-products and eco-processes. Nike for example developed an environmental apparel design tool to design eco friendly products while Adidas formalized a list of sustainability criteria for suppliers of raw materials. Timberland developed a Green Index to rate their products. On contrary interviewed SMEs are still far from applying any sustainability practice because they are still considered too expensive compared to the return they can give.

\section{$4 \quad$ Reference Model}

The Reference Model for supporting TCF companies to produce healthy and fashionable products results from the literature and the case-analysis and is based on developing the strategy for the supply network configuration and the detailed operative level on processes and activities definition along the four main dimensions (Knowledge, ICT, Organizational and Sustainability). 


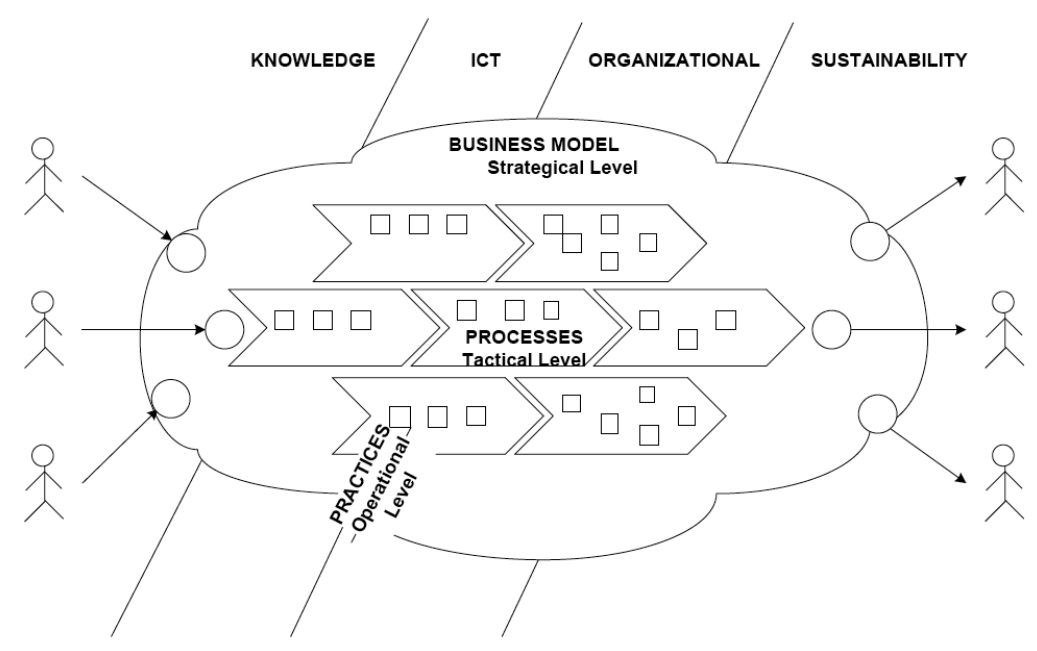

Fig. 1 - Reference Model Context Diagram

As depicted in fig.1 the Reference Model will support TCF companies at strategic level covering the overall collaboration framework of the supply chain, at process level it will support the definition of the processes which emerged as relevant for this kind of business and at operational level practices to be applied for different activities are considered. Regarding the Strategical Level, the business model framework proposed by Osterwalder (2004) was applied here. The model maps the most important building blocks that influence the definition of the value proposition. The idea is to instantiate this model to the specific case of TCF sector. Osterwalder (2004) widens this concept and defines Business Models as: "...a conceptual tool that contains a set of elements and their relationships and allows a company's logic of earning money. It is a description of the value a company offers to one or several segments of customers and the architecture of the firm and its network of partners for creating marketing and delivering this value and relationship capital, in order to generate profitable and sustainable revenue streams". In this regard, it is understood that business models should not only comprise the perspective inside organizations, but also embrace a wider perspective that includes potential partnerships, customers' requirements, revenue shares and other elements. The model have been applied also to collaborative networks extending the Ostervalder model (see Loss and Crave, 2011)). For the scope of this work we take into consideration the view on the single company in the need to network giving high emphasis to the partner network building block.

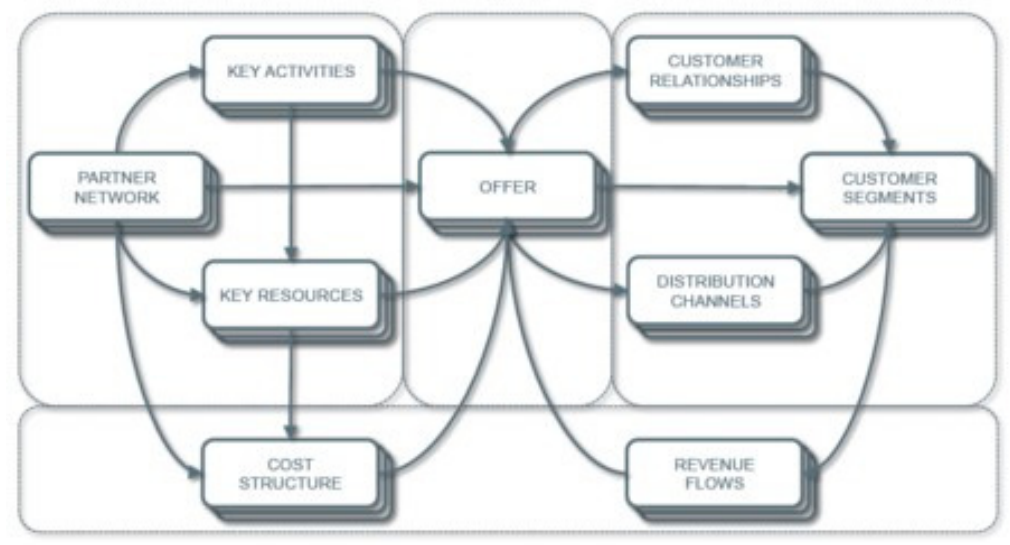

Fig. 2- Supply chain strategy based on building blocks 
In collaborative environments, value propositions can be considered common ground between collaborative networked organisations and customer communities. Collaborative networks should combine the capabilities of their members to create new abilities to better support the personalisation of experiences and with customer knowledge synergies co-create real personal value propositions where the consumer is starting to play an increasingly important role in the co-construction of value offers (Romero and Molina, 2011).

As an initial step of the approach to the definition of the strategy, the analysis of the as-is and to-be of the companies briefly described in chapter 3 has brought to the definition of the building blocks for two main categories of companies with completely different business model: on one side companies based on online business (B2C), where the direct contact via web gives the possibility to create easily new configuration spaces and to understand customers needs without intermediaries; on the other side companies based on traditional business model where the contact with final customer is filtered by the retailers and distributors and the manufacturer should provide a full service to shops in order to allow the configuration of the product both in terms of fashion and in terms of functional requirements. In the following table a short summary of the most important features of each building block for the 2 companies typologies is depicted.

\begin{tabular}{|c|c|c|}
\hline & Online e-tailor (SME) & Traditional SME (clothing or footwear) \\
\hline Target stakeholder & $\begin{array}{l}\text { End consumer (B2C) from target groups } \\
\text { e-tailers (electronic mail order business, e-shopping mall) } \\
\text { (B2B) in Europe }\end{array}$ & $\begin{array}{l}\text { - Multi-brand independent retailers } \\
\text { - Final end-users through own shops or web (web only for stock } \\
\text { production) from the target groups }\end{array}$ \\
\hline $\begin{array}{l}\text { Multi-value } \\
\text { proposition }\end{array}$ & $\begin{array}{l}\text { Make-to-measure (MTM) garments over the internet. In } \\
\text { particular garment where fashion for obese people and health } \\
\text { in terms of material transpirability, anti-sweating etc need to } \\
\text { be taken into consideration. }\end{array}$ & $\begin{array}{l}\text { Fashion garment and footwear for target groups. For garment it is } \\
\text { similar to the previous description for footwear fashion and health } \\
\text { features are taken into consideration considering features of shoes } \\
\text { from }\end{array}$ \\
\hline $\begin{array}{l}\text { Distribution } \\
\text { channel }\end{array}$ & $\begin{array}{l}\text { B2C - (e-commerce) direct to consumer via own e-shop } \\
\text { and/or indirect via e-tailors e-shops }\end{array}$ & $\begin{array}{l}\text { - Retailers (big / small) } \\
\text { - Own shops } \\
\text { - E-commerce (started experimental phase) } \\
\end{array}$ \\
\hline $\begin{array}{l}\text { Stakeholder } \\
\text { relationship }\end{array}$ & $\begin{array}{l}\text { - Periodic fit sessions to define and adjust configuration space } \\
\text { with TGs according to their needs } \\
\text { - Direct electronic communication to end-consumer using } \\
\text { internet interface and feedback (ranking, voting, } \\
\text { recommendations, ...) }\end{array}$ & $\begin{array}{l}\text { - usually big retailers create a forecast plan on next selling season } \\
\text { and related orders, only orders are exchanged with the company. } \\
\text { But this is not any more possible for small series production } \\
\text { dedicated to TGs. } \\
\text { - Fidelity card in owned shops to collect info about customer } \\
\text { behaviour } \\
\text { - Customer inputs and needs are continuously taken into account } \\
\text { in the development of new functionalities for the company's } \\
\text { products. }\end{array}$ \\
\hline Capabilities & $\begin{array}{l}\text { - data from KMT supporting the definition of the configuration } \\
\text { space } \\
\text { - CAD/CAM and MTM sizing technology and knowledge } \\
\text { - Web software technology and knowledge(B2C, B2B } \\
\text { configurator) } \\
\text { - Technology/knowledge for supply chain management of } \\
\text { MTO clothing manufacturing and delivery } \\
\text { - patented biometrics body measurement algorithm, needing } \\
\text { personal data, and measurement tape only optional. Enlarge } \\
\text { body measurement with special configuration space for obese } \\
\text { people. }\end{array}$ & $\begin{array}{l}\text { - Designers } \\
\text { - Knowledge on process and materials } \\
\text { - Strong partner networking } \\
\text { - Services and assistance to be provided to the customer in the } \\
\text { shop }\end{array}$ \\
\hline $\begin{array}{l}\text { Multi-value } \\
\text { configuration }\end{array}$ & $\begin{array}{l}\text { - Clothing development } \\
\text { - Management of MTO clothing manufacturing and delivery } \\
\text { - Software development and operation }\end{array}$ & $\begin{array}{l}\text { - R\&D on materials, product design } \\
\text { - Collaboration Management } \\
\text { - Marketing }\end{array}$ \\
\hline Partnerships & $\begin{array}{l}\text { - CMT manufactures for clothing production } \\
\text { - suppliers (weaver, finishing companies, trimmings) } \\
\text { - e-tailors } \\
\text { - communities } \\
\text { - service providers (PSP, postal check, ....) } \\
\text { - Technology provider (rendering, sizing) }\end{array}$ & $\begin{array}{l}\text { - Different partners to cover some phases of the process activities; } \\
\text { partners are involved in standard procedures and are selected } \\
\text { based on skill, equipment, delivery reliability, costs. } \\
\text { - For footwear company it will be important to activate contacts } \\
\text { with podiatrists, orthopaedic components producers, medical } \\
\text { device for foot measurement producer }\end{array}$ \\
\hline Revenue model & $\begin{array}{l}\text { - Direct sales of garments (payment before manufacturing) } \\
\text { - Commission model "click out" for "fashion rooms" of e-tailors } \\
\text { (payment before manufacturing) }\end{array}$ & $\begin{array}{l}\text { Revenue comes principally from direct sales of products to } \\
\text { customers according to the traditional business model of the pure } \\
\text { producer. Payments are usually delayed compared to delivery. } \\
\text { Consequently also payments from the manufacturer to the } \\
\text { suppliers are delayed. }\end{array}$ \\
\hline Cost structure & Marketing (Google, SEA, affiliates, on-line advertising, email) & $\begin{array}{l}\text { - Research \& Development } \\
\text { - Marketing } \\
\text { - Achieve the next phase of own products life-cycle (achieving the } \\
\text { growth phase) }\end{array}$ \\
\hline
\end{tabular}

Table 1: building blocks for 2 typologies of business model

Each building block of the Strategic Level needs to be declined within the second level of 
the model (Tactical Level), where the a set of critical processes which should be taken into consideration to reach the goals of the business model are analysed and described. These Business process emerged from the cross-case analysis as important to satisfy collaborative business requirements at network level. These processes have been mapped and formalized in a BPMN (Business Process Model Notation) representation (Fornasiero et al., 2011) as from the following overall picture.

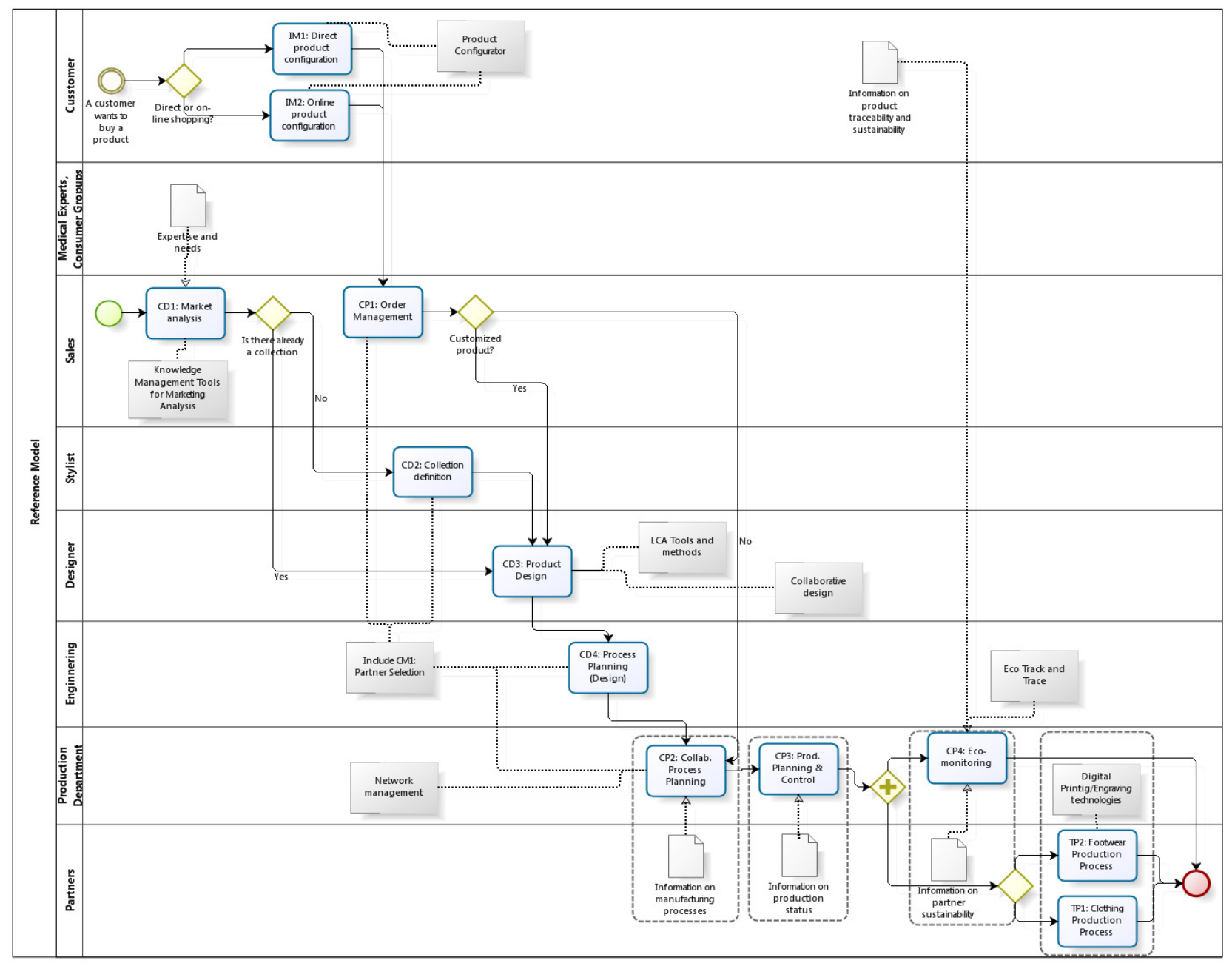

Fig. 3. BPMN representation of the mapped processes

The starting point of the overall process is twofold according to the level of customization/configuration it is decided for the Target groups to be addressed by the collaborative network.

On one side, in the fig. 3 the processes IM1 and IM2 represent the starting point from the customer. Traditional shopping as well as online configurators and customer profiling for specific customer groups are taken into consideration. IM1 and IM2 will allow direct customer interaction on footwear, textiles or clothing products with special features for the consumer target groups (elderly, obese, diabetics and disabled people) with the possibility of product configuration and full visualization of products characteristics.

On the other side, the identification of market needs and consumer preferences for new products and functionalities (CD1) are the starting point for the Definition of Product Collection (CD2) for specific target groups based on collaborative environment where 
different type of users (internal and external to the company) with different roles can contribute to define a collection of suitable products for the target consumers. Once the small series has been developed, Product Design with CAD modelling (CD3) is carried out by the (internal and external) designer and produces the CAD technical model of the product. Also includes selection of materials for both clothing and footwear.

Process planning (CD4) has the aim to decide how to manufacture the product. In this phase suppliers and outsourcers are identified and defined with the Partner Search and the costs for the different manufacturing phases are fixed. Also the BOM, the working cycles and the production times of the new product model are also defined. Customer order processing support (CP1) is based on automatic pre-processing of customer orders for administrative and pre-production checks and issues. The final output is the list of customer orders ready to be processed for production.

With collaborative process planning (CP2) all standard and default data can be uploaded to the early (automatic) set of Production Orders; external activities (to be outsourced) require the identification of potential partners to be assigned. The output is the set of production orders ready to be scheduled. In Collaborative production planning and control (CP3) production Orders related to the same customer's orders can be scheduled using a collaborative tool where Manufacturer and Partners can share a view of the production order schedules and close a "negotiation" for the definitive launch of manufacturing activities.

Last as a cross-cutting process the partner monitoring and trace support aims to monitor Production Orders as well as KPI related to Quality and Sustainability can be evaluated for that specific set of production orders. The outcome includes overall status, alerts/warnings and KPIs. For each of these processes a detailed description has been developed including information related to the flow of activities and related to the four dimensions of the model.

For each of these processes the collaboration level has been defined as well as the set of actions necessary to enrich the organizational, ICT and knowledge dimensions as well as the sustainability dimension.

The Operational Level is based on a set of practices that define the relationships between the business processes defined at tactical level and the four main dimensions (see table 2).

\begin{tabular}{|c|c|c|c|c|}
\hline $\begin{array}{l}\text { BUSINESS } \\
\text { PROCESSES }\end{array}$ & KNOWLEDGE & ICT & ORGANIZATIONAL & SUSTAINABILITY \\
\hline 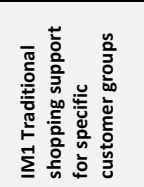 & $\begin{array}{l}\text { Customer involvement. Customer requirements } \\
\text { management. Clinical aspect and functional } \\
\text { requirements. }\end{array}$ & $\begin{array}{l}\text { Availability of machines like scanners, } \\
\text { cameras, virtual mirrors, etc.. able to get } \\
\text { images, 3D rendering of feet } \backslash \text { bodies for } \\
\text { product design. }\end{array}$ & $\begin{array}{l}\text { In a customer driven supply chain, end- } \\
\text { user demand drives all activities among } \\
\text { trading partners according to a culture that } \\
\text { puts the customer first. }\end{array}$ & $\begin{array}{l}\text { Commitment with the customer to } \\
\text { give information on sustainability. }\end{array}$ \\
\hline 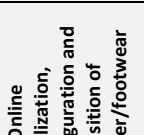 & $\begin{array}{l}\text { Formalized knowledge of information needed for } \\
\text { the customer to assess the performance of the } \\
\text { product. Companies should have clear and defined } \\
\text { knowledge of the status of the target group to } \\
\text { configure the products according to the needs. }\end{array}$ & $\begin{array}{l}\text { It is necessary to create a clear and single } \\
\text { access point that customers can recognize } \\
\text { as online shop. It is expecially necessary } \\
\text { for customer which can't move to buy } \\
\text { products (obese, elderly, disable people). }\end{array}$ & $\begin{array}{l}\text { Some steps realized by downstream supply } \\
\text { chain actors can be reduced compared to } \\
\text { direct sales. }\end{array}$ & $\begin{array}{l}\text { Formalized knowledge of } \\
\text { information needed for the customer } \\
\text { to assess the sustainability of the } \\
\text { products. }\end{array}$ \\
\hline 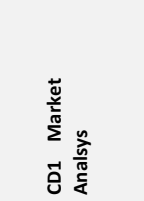 & $\begin{array}{l}\text { Need of data sharing agreements between retailers, } \\
\text { manufacturers and designers but also the } \\
\text { involvement of consumers through specific online } \\
\text { communities of consumer target groups. }\end{array}$ & $\begin{array}{l}\text { Tools for Data analysis based on semantic } \\
\text { web (ontology) tools for structured and } \\
\text { unstructured data; Customer profiling, } \\
\text { trend analysis features; Usage of OLAP, } \\
\text { Data Mining and Business Intelligence } \\
\text { tools; Integration with PDM for product } \\
\text { characterization; Collaboration Portals. }\end{array}$ & $\begin{array}{l}\text { Manufacturers and especially stylists and } \\
\text { designers need to identify specific } \\
\text { consumer groups in order to design and } \\
\text { develop the appropriated products and } \\
\text { accessories for these market niches and } \\
\text { not address the market as one. }\end{array}$ & $\begin{array}{l}\text { Connection with the social networks } \\
\text { to know which are the requirements } \\
\text { in terms of sustainability. Market } \\
\text { trends, Customer needs. }\end{array}$ \\
\hline
\end{tabular}




\begin{tabular}{|c|c|c|c|c|}
\hline 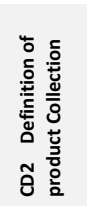 & $\begin{array}{l}\text { Knowledge on the specific functional requirements } \\
\text { of the customers. Share with experts specific } \\
\text { product features, enlarge the network to order } \\
\text { stakeholders like doctors, podiatrists, etc.. Open } \\
\text { innovation is a paradigm to be applied to involve } \\
\text { customers and other partners in the definition of the } \\
\text { product concept. }\end{array}$ & $\begin{array}{l}\text { PDM system with enhanced data } \\
\text { management ICT allowing to easily include } \\
\text { any kind of extended product features as } \\
\text { could be required for "functionalities" } \\
\text { related to specific consumer targets }\end{array}$ & $\begin{array}{l}\text { The creation of the new collection starts } \\
\text { from all the information collected and } \\
\text { formalized in CD1. At this stage } \\
\text { collaboration with stylists and suppliers is } \\
\text { relevant. }\end{array}$ & $\begin{array}{l}\text { Critical aspect for specific target } \\
\text { groups. Platform mapping } \\
\text { sustainable product and materials } \\
\text { available in the market. }\end{array}$ \\
\hline 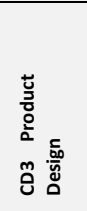 & $\begin{array}{l}\text { Product design should be based on the shared } \\
\text { concepts of: Modularity, Postponement, Product } \\
\text { innovation. }\end{array}$ & $\begin{array}{l}\text { Automatic tools and IT support for } \\
\text { product models deployments. After } \\
\text { product design Inclusion of product } \\
\text { virtual representation for IM1 and IM2, } \\
\text { taking into account the aesthetic and } \\
\text { functional requirements provided by the } \\
\text { customers. }\end{array}$ & $\begin{array}{l}\text { Important to involve suppliers in the choice } \\
\text { of materials and components during the } \\
\text { product design phase. }\end{array}$ & $\begin{array}{l}\text { Green product innovation. } \\
\text { Application of ECD, LCA, DFD, DFE, } \\
\text { DFR. Competencies on eco-materials, } \\
\text { competencies on functional aspects } \\
\text { related to each material. Eco-design } \\
\text { practices. }\end{array}$ \\
\hline 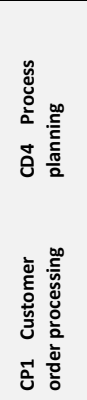 & $\begin{array}{l}\text { New solutions in terms of new process plans, as well } \\
\text { as reduces the time needed to reach satisfactory } \\
\text { solutions. } \\
\text { (a) the analysis and translation of the product } \\
\text { configuration information into the production article } \\
\text { data in terms of materials and production processes } \\
\text { (for lot size 1, and for small series). (b) Aggregation } \\
\text { of orders. } \\
\text { (c) Partner selection in order to collaborate with } \\
\text { them. }\end{array}$ & $\begin{array}{l}\text { Definition of the generic process plan and } \\
\text { subsequently for the construction, } \\
\text { simulation and finally the definition of the } \\
\text { detailed process plan. Specific process } \\
\text { planning and simulation tools are } \\
\text { required. } \\
\text { Product data (measures and configuration } \\
\text { options) is required for the process } \\
\text { planning finalization where the product } \\
\text { model and working instructions/tools can } \\
\text { be finalized. }\end{array}$ & $\begin{array}{l}\text { Involve suppliers in the process planning in } \\
\text { the design phase of the supply chain. Their } \\
\text { collaborative contribution is fundamental } \\
\text { in order to the production engineer } \\
\text { accomplish efficient, balanced and resilient } \\
\text { solutions. } \\
\text { Production orders are generated taking } \\
\text { into consideration different customer } \\
\text { orders arrived in the period of time used } \\
\text { for decision taking. In small series orders, } \\
\text { production orders are the results of the } \\
\text { aggregation of different customer orders. }\end{array}$ & $\begin{array}{l}\text { Eco-friendly raw material, TQEM, } \\
\text { Green manufacturing and re- } \\
\text { manufacturing, Reverse logistic, } \\
\text { Environmental awards, ISO } \\
\text { certification. } \\
\text { Optimizing order processing based } \\
\text { on criteria linked to save resources } \\
\text { and to reduce pollution. }\end{array}$ \\
\hline 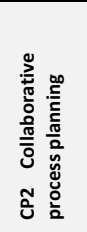 & $\begin{array}{l}\text { Informations already stored in the PDM system and } \\
\text { related to generic BOM and working cycles for } \\
\text { product models. Order specific information that will } \\
\text { integrate these will have to be coherently structured } \\
\text { according to a common framework. }\end{array}$ & $\begin{array}{l}\text { special designs and modifications set by } \\
\text { end users in the shop. } \\
\text { Collaboration tools to communicate with } \\
\text { selected partners and send them the so } \\
\text { created PO. } \\
\text { Integration with PDM } \backslash \text { ERP to register the } \\
\text { order on partners side. }\end{array}$ & $\begin{array}{l}\text { The creation of the PO is realized } \\
\text { integrating basic information already } \\
\text { defined and stored, as the generic working } \\
\text { cycle and BOM, for the product models } \\
\text { required in the customer order and } \\
\text { information order specific information as } \\
\text { the ones related to personalization options } \\
\text { (esthetical). }\end{array}$ & Acquisition of supplier availability. \\
\hline 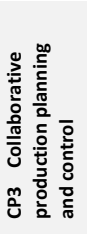 & $\begin{array}{l}\text { Impact of the right or wrong production on the } \\
\text { pathologies. }\end{array}$ & $\begin{array}{l}\text { At this level it is necessary to have a } \\
\text { collaborative process tools supporting the } \\
\text { Production Planning of external activities } \\
\text { and a workflow control for the whole } \\
\text { customer/production orders. }\end{array}$ & $\begin{array}{l}\text { Collaborative planning includes aspects } \\
\text { that enable partners to recognize how } \\
\text { individual companies plans should be } \\
\text { adapted, according to which criteria the } \\
\text { planning can be optimized, and which } \\
\text { restrictions in the common planning must } \\
\text { be } \\
\text { accepted. }\end{array}$ & $\begin{array}{l}\text { Collaboration/integration with } \\
\text { partners and suppliers in order to } \\
\text { implement pollution preventive } \\
\text { technologies. }\end{array}$ \\
\hline 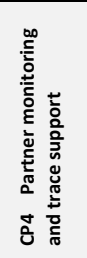 & $\begin{array}{l}\text { Ability to include in the definition of KPIs proper } \\
\text { inputs from final customers requirements and } \\
\text { needs, especially the ones belonging to the target } \\
\text { groups addressed by the project as, for example in } \\
\text { terms of anallergic and no toxic materials. }\end{array}$ & $\begin{array}{l}\text { It must be defined and released a set of } \\
\text { KPIs (ontology, vocabulary, etc...) that } \\
\text { define different aspects related to quality } \\
\text { and sustainability. } \\
\text { Web services must be written to check } \\
\text { such KPIs and confront them with the } \\
\text { producers' processes and raw material } \\
\text { origin to elaborate a final judgment on the } \\
\text { product. }\end{array}$ & $\begin{array}{l}\text { First of all a set of proper KPIs referred to } \\
\text { Quality aspects have to be defined. This is } \\
\text { done by the production department and } \\
\text { can be based on inputs from customer } \\
\text { groups targeted by the project and } \\
\text { referred to their specific requirements and } \\
\text { needs. }\end{array}$ & $\begin{array}{l}\text { Long-term relationship with } \\
\text { partners, Environmental } \\
\text { Performance Indicators. }\end{array}$ \\
\hline
\end{tabular}

\section{Conclusions}

This research work proposes a reference model to implement an innovative consumercooperative environment to enable European TCF companies to produce and deliver small series of specialized and customized high value products. The industrial and empirical nature of the RM guarantees full feasibility of its guidelines.

In particular, the RM represents a formalization of a methodology that can be applied to companies to support them in understanding which are the most important steps to be improved in their business. The RM is supported by sustainable methods and tools for product design, planning, production activities, rapid manufacturing technologies which are under development in the project CoReNet.

The RM aims to facilitate TCF supply networks in managing consumers' data to know their needs, involve consumers in product design and configuration, exchange consumers' data through adequate data models and secure systems, collaborate with suppliers, implement innovative manufacturing machines, monitor quality and sustainability of products. The 
model is under evaluation with companies in the sector and all the different dimensions will be further analyzed and developed according to the results of the research.

\section{Acknowledgement}

This work has been partly funded by the European Commission through the FP7-2010-NMP-ICT-FoF Project CoReNet: "Customer-Oriented and Eco-Friendly Networks for Healthy Fashionable Goods" (Grant Agreement 260169). The authors wish to acknowledge the Commission for the support.

\section{References}

Adler P.S. 2001. Market, Hierarchy and Trust: the Knowledge Economy and the Future of Capitalism. Organization Science. 12(2) pp.215-234.

Azevedo A., Bastos J., Almeida A., Magaletti N., Del Grosso E., Stellmach D., Winkler M., Fornasiero R., Zangiacomi A., Chiodi A.: Customer-Oriented and Eco-friendly Networks for Health Fashionable Goods The CoReNet Approach, PRO-VE conference, 2011, Brasil

Boer C.R. and Dulio S. 2007. Mass customization and footwear: myth, salvation or reality? A comprehensive analysis of the adoption of the mass customization paradigm in footwear, from the perspective of EUROShoE Research Project. Springer.

Camarinha-Matos L.M., Boucher X., Afsarmanesh H. 2010. Collaborative Networks for a Sustainable World 11th IFIP WG 5.5 Working Conference on Virtual Enterprises, Proceedings.

Childerhouse, Paul, Aitken, James, and Towill, Denis R. 2002. Analysis and design of focused demand chains. Journal of Operations Management. 20(6), 675-189.

De Treville, Suzanne, Shapiro, Roy D., and Hameri, Ari-Pekka. 2004. From supply chain to demand chain: the role of lead time reduction in improving demand chain performance. Journal of Operations Management. 21(6), 613-627.

Dyer J.H., Singh H. 1998. The Relational View: Cooperative Strategy and Source of Interorganizational Competitive Advantage. Academy of Management Review. 23(4) pp.660-679.

Eisenhardt K.M. 1989. Building theories from case study research. Academy of management review. 14(4) pp.532-550.

Eisenhardt K.M., Graebner M.E. 2007. Theory building from cases: Opportunities and challenges. Academy of management journal. 50(1) pp.25- 32 .

Europe's demographic future: Facts and figures on challenges and opportunities, European Commission, Directorate-General for Employment, Social Affairs and Equal Opportunities, 2007.

Filos, E. and Banahan, E.: Towards the smart organization: An emerging organizational paradigm and the contribution of the European RTD programs, in: Journal of Intelligent Manufacturing, Vol. 12(2), Springer Netherlands, S. 101-11 (2001).

Fornasiero R., Zangiacomi A., Stellmach D.: A Reference Model for Customer-Oriented and Eco-Friendly Networks for Healthy Fashionable Goods, proceedings of the APMS2010 International Conference on Advances in Production Management Systems. Stavanger (Norway), 26-28 September 2011.

Gereffi G., Humphrey J., Sturgeon T. 2005. The governance of global value chains. Review of International Political Economy. 12(1) pp.78-104.

Glaser B. and Strauss A. (1967). Grounded Theroy: the discovery of grounded theory. Chicago. Aldine.

Grefen P. et al. 2009. Dynamic business network process management in instant virtual enterprise. Computers in Industry. 60 pp.86-103.

Leonidou L.C. 2004. An analysis of the barriers hindering small business export development. Journal of small business management. 42(3) pp.279-302.

Loss, L. and Crave, S. (2011). Agile Business Models: An Approach to Support Collaborative Networks. Production Planning \& Control: The Management of Operations. 22(5-6), pp. 571-580.

Osterwalder, A. (2004). "The Business Model Ontology a Proposition in a Design Science Approach", PhDThesis, Lausanne University, Switzerland.

Osterwalder, A. and Y. Pigneur (2010). Business Model Generation - A Handbook for Visionaries, Game Changers, and Challengers. Hoboken - New Jersey, John Wiley \& Sons, Inc.

Pagell M. (2004) Understanding the factors that enable and inhibit the integration of operations, purchasing and logistics. Journal of Operation Management. 22(5) pp.459-487.

Piller, F., Tseng, M. New directions for Mass Customization. The Customer centric enterprise. Advances in mass customisation, Springer, 2003.

Romero, D. and Molina, A. (2011). Collaborative Networked Organisations and Customer Communities: Value Co-Creation and Co-Innovation in the Networking Era. Production Planning \& Control: The Management of Operations. 22(5-6), pp. 447-472.

Yin R.K. 1994. Case Study Research. Design and Methods. Thousand Oaks. Sage. 
Yeung H.T, Choi T.M, Chiu C.H. Innovative Mass Customization in the Fashion Industry. International Handbooks on Information Systems. 423-454, 2010. 